\title{
Physico-Chemical Profiles of Croatian Honey with an Overview of Its Consumption among Healthcare Students
}

1 Natalija Uršulin-Trstenjak

1 Davor Levanić

1 Ivana Grabar

1 Marijana Koldenjak

2 Jasna Bošnir

1 University North, University Center Varaždin, Varaždin

2 Andrija Stampar Teaching Institute of Public Health, Zagreb

\section{Abstract}

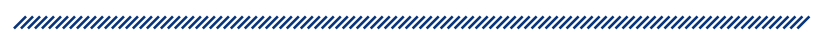

Consumers are becoming more aware of consumption of honey - the food with properties beneficial for health.

In accordance with The European Union Council Directive Relating to Honey, as well as with the current legislation in the Republic of Croatia, the requirement for labeling the botanical origin of nectar honey is the presence of the dominant flower pollen as well as sensory and physicochemical analysis.

The paper is a confirmation of botanical origin, the profile of physicochemical parameters with differences within the seasons/regions and the consumption of honey.

This research covered 200 samples of black locust honey, collected from beekeepers during two seasons in five Croatian regions - 20 samples from each region. A survey was conducted among 151 students to gather information on their honey consumption habits.

The method used in the paper was melissopalynological and physicochemical analysis, ANOVA and a survey.
All the tested samples contain the sufficient number of pollen grains $>20 \%$ of Robinia pseudoacacia. The results of physicochemical quality parameters are as follows: mean water 15.99-18.03\%; free acids 8.16-12.94 $\mathrm{mEq} / 1000 \mathrm{~g}$; electrical conductivity $0.12-0.22 \mathrm{mS} / \mathrm{cm}$; reducing sugars $66.94-70.88 \mathrm{~g} / 100 \mathrm{~g}$; sucrose $0.10-2.90$ g/100g; diastasis 9.07-15.14 DN; HMF 0.50-18.99 mg/ $\mathrm{kg}$. Conducted data analysis of variance within physicochemical parameters regarding seasons and regions showed statistically significant difference among seasons $p<0.05$ for water, while for diastasis activity it showed statistically significant difference among regions $\mathrm{p}<0.05$.

Out of $141(93 \%)$ respondents who consume honey, 63 $(44 \%)$ of them consume it in quantities which are smaller than the Croatian average.

Keywords: black locust honey, physicochemical parameters, botanical origin

Article received: 17.10.2016.

Article accepted: 15.05.2017.

DOI: $10.24141 / 3 / 1 / 6$

Corresponding author:

Natalija Uršulin-Trstenjak

University North, University Center Varaždin

104. brigade 3, 42000 Varaždin

E-mail: natalija.ursulin-trstenjak@unin.hr

Phone: +38542466388 


\section{INTRODUCTION}

Consumers in Croatia and the region are becoming increasingly aware of food consumption with strong properties beneficial for health, such as honey and bee products. Average consumption of honey per capita in Croatia is very low (400 g) compared to Western European countries (from 3 to $8 \mathrm{~kg}$ ). Bee products are directly marketed or are purchased by beekeeping companies. These companies create added value through many brands and product lines and market the products through the channels of the wholesale, retail and export. Beekeepers have the option of selling bee products 'at the doorstep' or the household farm. It is even more important to have direct contact with customers and indicate the importance of using bee products in the daily diet and emphasize the beneficial effect bee products have on human health. ${ }^{1}$

By chemical composition, honey is a complex mixture of over 70 compounds, which come in honey in different ways (added by bees, originate from honey producing plants or as a result of honey ripening in honeycomb). ${ }^{2}$ Variability and non-existence of two honey samples that are the same are characteristics that best describe chemical composition of honey. Not only that various types of honey differ, but even within the same type of honey there are differences in composition dependent on their geographic origin, climate conditions, breeds of bees and work of a beekeeper (the way of honey finishing and storage). ${ }^{3-5}$ The most common ingredients which represent $99 \%$ of honey are carbohydrates (mostly fructose and glucose) and water. Other substances (represent only < 1\%) are proteins (including enzymes), minerals, vitamins, organic acids, phenolic compounds, aromatic substances (volatile) and various chlorophyll derivatives which are also responsible for sensory and nutritional properties of honey. ${ }^{4,6}$

Black locust, which originates from the northeastern part of the United States, is naturalized and cultivated in Europe. Black locust honey is mainly produced in the eastern European countries, where the largest amounts come from, and outside Europe in China. It is one of the most valuable types of honey in the European market with the characteristics valued by consumers: it is liquid, not prone to crystallization, of a very bright color, with floral or of fresh fruit scent, and the taste less pronounced and light (medium to strong sweetness, low acidity and flavor without bitterness). In Croatia, the largest produc- tion pertains to the production of black locust honey with the most generous pastures in the continental parts. The underproduction of black locust pastures is very frequent, given the time of flowering, which in continental areas happens during adverse weather conditions (cold and rainy or very hot and windy). 7,8

The large number of European countries have a national legislative and reference methods used for local quality check, but they are often specific to a particular country and may not always be applicable in the commercialization of honey in international sales. The International Honey Comission (IHC) endeavors to harmonize the reference methods and standards for proving the authenticity of botanical origin of unifloral type of honey. ${ }^{9,10}$

Leading experts involved in these issues combine melissopalynological determination of the type and number of pollen with sensory analysis and physicochemical analysis, such as the determination of water content, HMF (hydroxymethylfurfural), electrical conductivity, diastase activity, pH value, and sugar content (fructose, glucose, sucrose, erlose, raffinose, melezitose). ${ }^{11-14}$

In this research the aims were to confirm the botanical origin of honey, which is declared by the manufacturer, to determine the profile of physicochemical parameters of Croatian black locust honey by seasons and regions, and to point out their differences within each analyzed season and region.

\section{METHODS}

\subsection{Subjects}

This study included 200 samples of black locust honey, collected from beekeepers through two seasons (season 1 and season 2) in 5 Croatian regions, 20 samples from each region: VŽ (Varaždin), KZ (Krapina-Zagorje), BB (Bjelovar-Bilogora), IH (Eastern Croatia) and I (Istria), or from eight counties: Varaždin, Krapina-Zagorje, BjelovarBilogora, Požega-Slavonia, Brod-Posavina, Osijek-Baranja, Vukovar-Srijem i Istria. Until the analysis, the samples were stored under controlled conditions, in the dark at room temperature (Figure 1).

The survey was conducted among 151 students of Nursing at University North (23 male and 77 female students). 


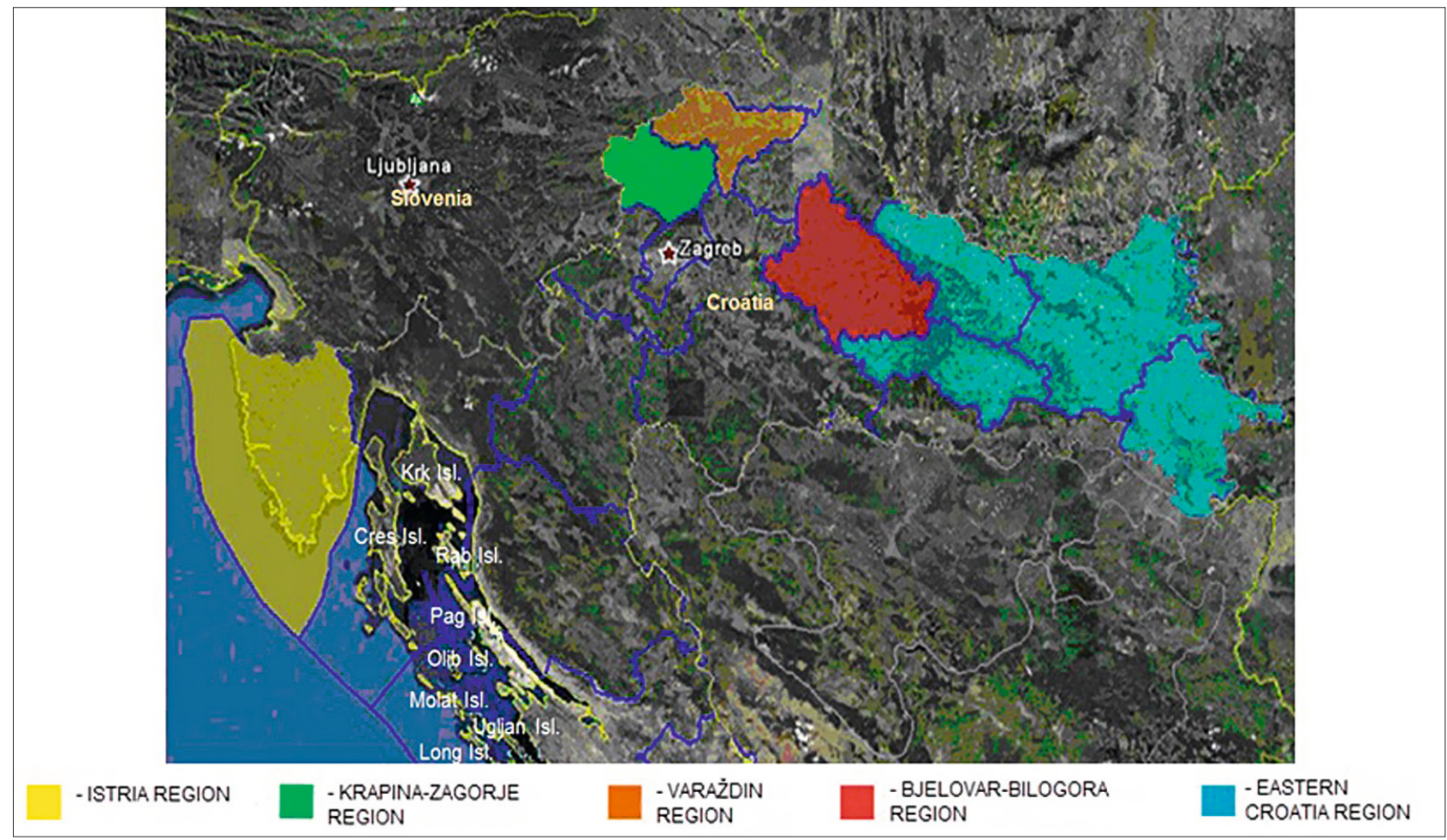

Figure 1. The map of geographic origin of honey

\subsection{Methods}

Determination of the relative content of pollen in the honey was conducted microscopically using collection of reference pollen preparations, which was used for the determination of pollen grains from the specimens. ${ }^{15}$

The water content of honey was determined by the method prescribed by the International Honey Commission, which is based on refractometry. ${ }^{16}$

Determination of free acids in honey was conducted in a way that the prepared sample was titrated with the solution of $0.1 \mathrm{M}$ sodium hydroxide to a $\mathrm{pH}$ of 8.30 , according to the method prescribed by the International Honey Commission. ${ }^{16}$

Electrical conductivity of honey was defined as conductivity of $20 \%$ aqueous solution of honey at $20^{\circ} \mathrm{C}$, where $20 \%$ refers to the dry matter of honey. Results are expressed in $\mathrm{mS} / \mathrm{cm}^{16}$

Determination of reducing sugars and sucrose in honey was based on the reduction of Fehling's solution by titration with a solution of sugar from honey, and with the use of methyl blue as an indicator, while the proportion of sucrose was obtained from the difference between the results obtained after and before the inversion. ${ }^{16}$
Determination of diastase activity in honey was based on the hydrolysis of $1 \%$ solution of starch by the enzyme from $1 \mathrm{~g}$ of honey during one hour at a temperature of $40^{\circ} \mathrm{C} .16,17$

Determination of hydroxymethylfurfural (HMF) in honey was conducted using the Winkler method based on the reaction of the hydroxymethylfurfural with the barbituric acid and $\mathrm{p}$-toluidine, to produce a pink color, whose intensity is measured at a wavelength of $550 \mathrm{~nm} \cdot{ }^{16,17}$

Statistical analysis includes the mean value, standard deviation and coefficient of variability of selected physicochemical parameters in samples of black locust honey. To compare the properties of honey across regions and seasons, a two-way analysis of variance (ANOVA) was performed, using software package STATISTICA 9.1. ${ }^{18}$

\subsection{Survey}

The students of Nursing were asked to fill in a questionnaire which included obtaining the data on the consumption of honey (the reason, the frequency and amount of consumption of honey), on the point of purchase (the place and the criteria of honey purchase), and the knowledge of physicochemical parameters of honey. 


\section{RESULTS AND DISCUSSION}

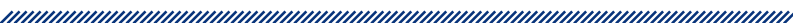

This study included a total of 200 samples of black locust honey, collected from beekeepers in five Croatian regions: VŽ, KZ, BB, IH and I. From each region, 20 samples of black locust honey were collected, which had been extracted during two seasons, 2009 and 2010 (season 1 and season 2).

Conducted melissopalynological analysis showed that all samples have more than $20 \%$ of Robinia pseudoacacia (black locust family) pollen grains. The range of Robinia pollen grains in tested individual samples is from $22 \%$ to $71 \%$ (Table 1 ).

\begin{tabular}{|c|c|}
\hline REGION - SEASON & Robinia pseudoacacia \% \\
\hline VŽ & $24-65$ \\
\hline KZ & $23-68$ \\
\hline BB & $23-59$ \\
\hline IH & $22-60$ \\
\hline 1 & $33-71$ \\
\hline
\end{tabular}

Table 2 gives an insight into the results of analysis of seven studied physicochemical parameters (water content, free acids, electrical conductivity, reducing sugars, sucrose, HMF and diastase) in black locust honey by region through two seasons (season 1 and season 2) on a total of 200 samples collected, with a range of mean values for each parameter: water 15.99-18.03\%; free acids $8.16-12.94 \mathrm{mEq} / 1000 \mathrm{~g}$; electrical conductivity 0.12-0.22 mS/cm; reducing sugars $66.94-70.88 \mathrm{~g} / 100 \mathrm{~g}$; sucrose 0.10-2.90 g/100g; diastasis 9.07-15.14 DN; HMF $0.50-18.99 \mathrm{mg} / \mathrm{kg}$.

Using two-way analysis of variance (ANOVA), the significance of differences within certain physicochemical parameters, depending on the season and region of origin of black locust honey, was shown. It is evident that there is a statistically significant difference among seasons $(p<0.05)$ for water 0.026 , while diastase 0.017 activity showed a statistically significant difference between regions $(p<0.05)$ (Table 3).

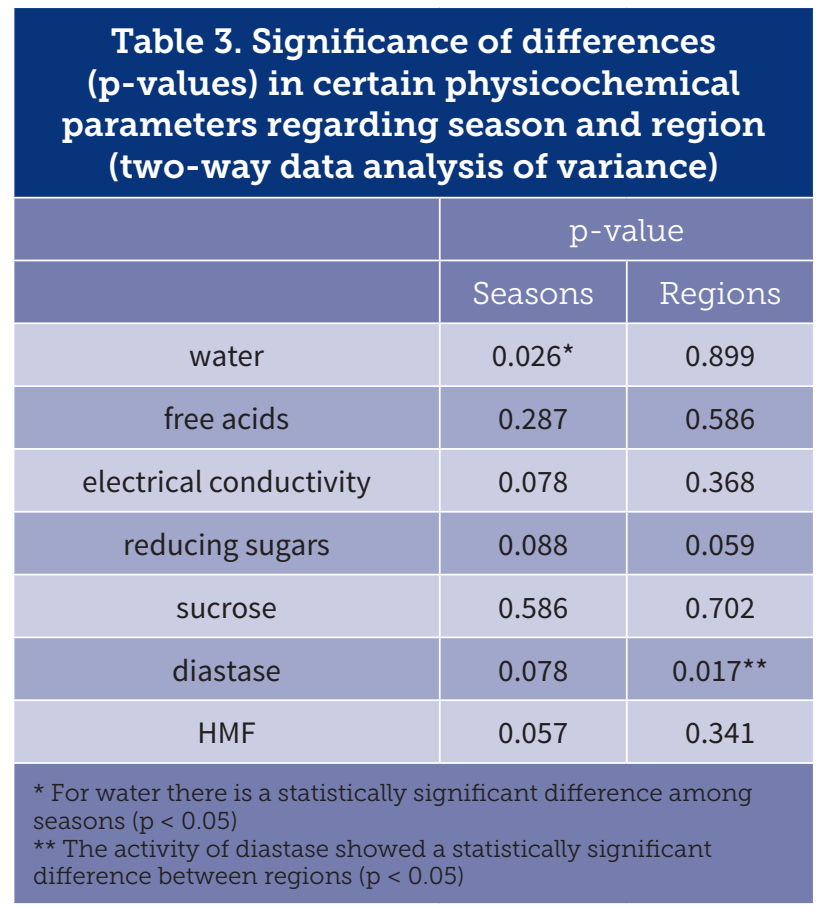

The survey results show that 141 students (93\%) consume honey ( 22 men and 128 women). When choosing the honey, 25 students (17\%, 4 men and 21 women) consider the price to be an important criterion. For the purchase/procurement of honey, 62 respondents (43\%) pay attention to the declaration, and only 10 respondents (7\%) ask for the Analytical Report. Information on the quantity of honey that the students consume when compared to the Croatian average ( $400 \mathrm{~g} / \mathrm{year}$ ) shows that $38(27 \%)$ of them consume more, $63(44 \%)$ less, and $40(29 \%)$ in accordance with the Croatian average.

In accordance with The European Union Council Directive Relating to Honey, as well as with the current legislation in the Republic of Croatia, the requirement for labeling of botanical origin of nectar honey is the presence of the dominant flower pollen, either unifloral or multifloral. ${ }^{11,12,19}$ Confirmation of the botanical origin of honey samples of this study, as declared by the manufacturer, was conducted by melissopalynological analysis, with a sufficient number of Robinia (black locust families) pollen grains $>20 \%$, by which they can be classified into unifloral black locust honey. The sample with the least of Robinia pollen grains (22\%) was from IH region, and the one with most $(71 \%)$ is from I region (Table 1$)$.

In recent years, what has been prominent is the combination of quality parameters that alongside the number of pollen and sensory analysis includes the determination of physicochemical parameters. ${ }^{20,21,10,22,5}$ The 


\section{Table 2. Physicochemical profile of black locust honey through two seasons in five regions}

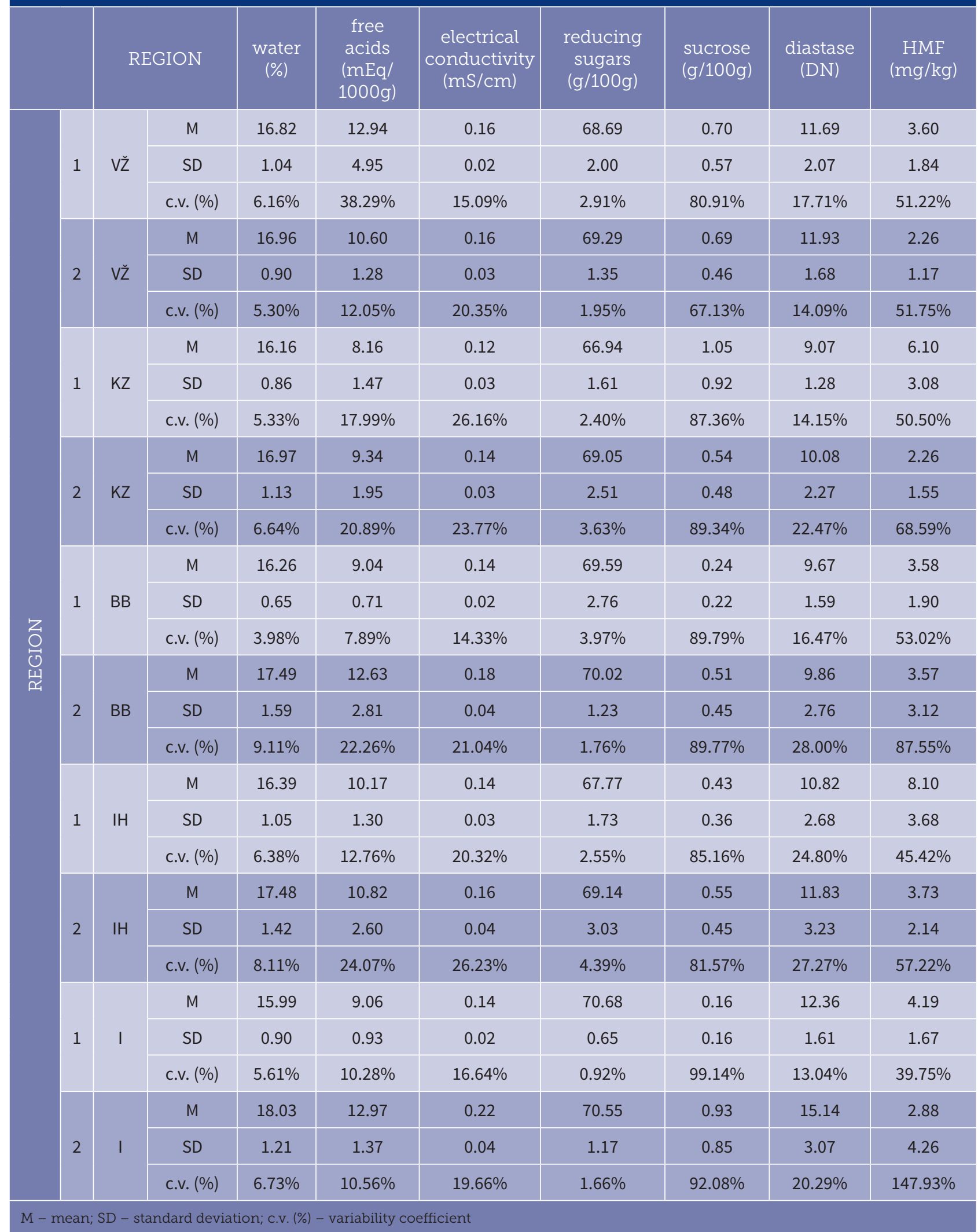


obtained mean results of physicochemical parameters (water, free acids, electrical conductivity, reducing sugars, sucrose, diastasis, HMF) are in conformity with the requirements of the regulations on the quality of unifloral honey ${ }^{19}$ and the international literature data on black locust honey: water $15.99-18.03 \%$; free acids 8.16-12.94mEq/1000g; electrical conductivity 0.12-0.22 $\mathrm{mS} / \mathrm{cm}$; reducing sugars $66.94-70.88 \mathrm{~g} / 100 \mathrm{~g}$; sucrose 0.10-2.90 g/100g; diastasis 9.07-15.14 DN; HMF 0.50$18.99 \mathrm{mg} / \mathrm{kg}$ (Table 2).

The water content in the analyzed samples was below $20 \%,{ }^{12}$ mean values ranged from 15.99 to $18.03 \%$, which is in accordance with the results of other researchers on samples of black locust honey from Croatia (15.40 to $16.30 \%)$, Romania (17.90\%), results of Kenjerić et al. (also from Croatia) in a two-year period $(16.50 \%$ and $16.10 \%)$, as well as with Italian researchers (17.1\%). ${ }^{8,23-}$ ${ }^{25}$ Allowed value of free acids in honey is $<50 \mathrm{mEq}$ of acid/1000g of honey ${ }^{12}$, which confirms the accordance of average values in this study ranging from 8.16 to $12.94 \mathrm{mEq} / 1000 \mathrm{~g}$. Literature data shows different values of free acids in samples of black locust honey in comparison with this research. The average values are less than or equal to those obtained by Golob and Plestenjak (24 mEq /1000g) and Kenjerić et al. (10.7 $\mathrm{mEq} / 1000 \mathrm{~g} ; 10.1 \mathrm{mEq} / 1000 \mathrm{~g})$, but equal to or slightly higher than the results of Šarić et al. and Marghitas et al. (7.3-8.4 mEq/1000g; $6.45 \mathrm{mEq} / 1000 \mathrm{~g}, 11.2 \mathrm{mEq} / 1000 \mathrm{~g}$ ), as well as those obtained by Italian researchers (11.2 $\mathrm{mEq} / 1000 \mathrm{~g})^{26,24,8,23,25}$. The average values of electrical conductivity in the samples of this study were 0.12 to $0.22 \mathrm{mS} / \mathrm{cm}$, which meets the general requirements of a maximum of $0.8 \mathrm{mS} / \mathrm{cm}^{12}$. Those are equal to the results obtained with the 513 samples of European black locust honey $(0.16 \mathrm{mS} / \mathrm{cm})$, and the average obtained by Popek $(0.22 \mathrm{mS} / \mathrm{cm})$, Marghitas et al. $(0.15-0.20 \mathrm{mS} /$ $\mathrm{cm})$, Sarco et al. $(0.11 \mathrm{mS} / \mathrm{cm})$, Kenjerić et al. $(0.12 \mathrm{mS} /$ $\mathrm{cm})$, but lower than the average of Slovenian black locust $0.26 \mathrm{mS} / \mathrm{cm}^{25,27,23,8,24,26}$. The sum of the glucose and fructose (i.e. reducing sugars) shares in honey must be at least $60 \mathrm{~g} / 100 \mathrm{~g}^{12}$. At the level of the European research on 454 samples of black locust honey, the average value obtained was $69.2 \mathrm{~g} / 100 \mathrm{~g}^{25}$, in which range are also the values obtained in this study, from 66.94 to $70.68 \mathrm{~g} / 100 \mathrm{~g}$. Other literature sources also show the results matching this research $(67.4$ to $71.5 \mathrm{~g} / 100 \mathrm{~g}, 70.5$ $\mathrm{g} / 100 \mathrm{~g}, 71.13 \mathrm{~g} / 100 \mathrm{~g})^{8,28,23}$. All samples analyzed met the requirement of sucrose share (up to $10 \mathrm{~g} / 100 \mathrm{~g}$ of the sample $)^{12}$. It ranges from 0.10 to $2.90 \mathrm{~g} / 100 \mathrm{~g}$ and is equal to those obtained in black locust honey samples of the researchers from Romania $(1.55 \mathrm{~g} / 100 \mathrm{~g})$, Croatia (2.4-4.9 g/100g; $2.8 \mathrm{~g} / 100 \mathrm{~g})$ and Italy $(2.1 \mathrm{~g} / 100 \mathrm{~g})^{23,28,25}$. General requirement for diastase activity value is $8 \mathrm{DN}$, except for types with low enzyme activity (citrus, black locust) where the DN can be $<8$, but the proportion of HMF then must be $\leq 15 \mathrm{mg} / \mathrm{kg}^{12}$. The obtained averages are 9.07 to $15.14 \mathrm{DN}$ and follow European (10.5 DN) and other Croatian results for black locust honey ${ }^{25,8}$. The share of HMF is low - a very large percentage of honey samples had less than $10 \mathrm{mg} / \mathrm{kg}$ (which is considered to be the upper limit for the first-class honey) ranging from 2.26 to $8.10 \mathrm{mg} / \mathrm{kg}$, which are below the average values obtained by Šarić et al., also on samples of the Croatian black locust honey (from 4.7 to $36.5 \mathrm{mg} / \mathrm{kg})^{8}$. The individual values are from 0.50 to $18.99 \mathrm{mg} / \mathrm{kg}$ (Table 4).

Table 4. Physicochemical parameters of black locust honey (range of average values of all
regions from both seasons)


Today, other methods for determining the parameters of honey are being considered - such as spectroscopic techniques - which would replace the existing methods that are unsuitable for processing large numbers of samples since it takes some time to obtain results and the analysis costs are high ${ }^{9}$.

By using two-way analysis of variance, the insight into the significance of differences ( $p$-value) was obtained for certain physicochemical parameters, depending on the season and region of origin of black locust honey. It is evident that, for water, there is a statistically significant difference among seasons $(p<0.05)$, whereas the activity of diastase showed a statistically significant difference between regions $p<0.05$ (Table 3 ).

By conducting the research on a convenience sample of 151 nursing students, we came to the conclusion that 141 of them $(93 \%)$ consume honey. With regard to the quantities of honey consumed compared to the Croatian average ( $400 \mathrm{~g} /$ year), 38 of them $(27 \%)$ consume more, 63 (44\%) less and $40(29 \%)$ in accordance with the Croatian average. Given the importance of factors that affect the purchase of honey - the price or type of honey - the price is important for 25 students (17\%) (4 men and 21 women), while for the other respondents the type of honey primarily affects the purchase. When purchasing/procuring honey, 62 respondents (43\%) look at the label and only 10 respondents (7\%) ask for Analytical Report. The data also show that 37 (26\%) of the respondents consume honey for its health benefits, $43(30 \%)$ for the prevention of illness and 61 (44\%) use it as a sweetener. The data show respondents are becoming increasingly aware of the benefits provided by the food with enhanced health properties.

\section{CONCLUSIONS}

Conducted melissopalynological analysis confirmed the botanical origin of all honey samples in both seasons and all regions, as it was declared by the manufacturer - black locust honey.

The results of physicochemical quality parameters (water, HMF, electrical conductivity, diastase activity, $\mathrm{pH}$ values, sugar such as fructose, glucose, sucrose) meet the criteria set by the regulations on honey ${ }^{12}$.
The analysis of variance of data within the physicochemical parameters, regarding season and region, shows that, for water, there is a statistically significant difference among seasons $p<0.05$, whereas the activity of diastase showed a statistically significant difference between the regions $p<0.05$.

Of the total surveyed students, $93 \%$ of the respondents consume honey. Most consume honey with the purpose of prevention and as a sweetener, which confirms they are familiar with the importance that honey has for health. However, the quantity of consumption corresponds to the Croatian average.

\section{REFERENCES}

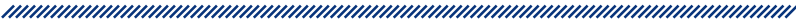

1. Petrović I. Pčelarska proizvodnja na obiteljskom gospodarstvu. HZPSS, Zagreb, 2010. [online]. Available: http:// www.agroklub.com/agro-hobi/pcelarska-proizvodnjanaobiteljskomgospodarstvu/3107/ (Accessed 12.10.2015.)

2. Krell R. Value-added products from beekeeping. Ch. 2 . FAO Agricultural Services Bulletin 124; 1996.

3. Škenderov S, Ivanov C. Pčelinji proizvodi i njihovo korišćenje. Beograd: Nolit; 1986.

4. Vahčić N, Matković D. Kemijske, fizikalne i senzorske značajke meda [online]. 2009. Available:http://www.pcelinjak.hr/OLD/index.php/Prehrana-i-biotehnologija/kemijske-fizikalne-i-senzorske-znaajke-med.html (Accessed 01.10.2011.)

5. Uršulin-Trstenjak N, Hrga I, Stjepanović B, Dragojlović D, Levanić $D$. Determination of botanic origin of the Croatian black locust honey (Istria region) using melissopalynological analysis. Journal of Hygienic Engineering and Design. 2013;4:122-6.

6. Singhal RS, Kulkarni PR, Rege DV. Handbook of indices of food quality. Cambridge: Woodhead Publishing. 1997;358-379.

7. Šimić F. Naše medonosno bilje. Zagreb: Znanje; 1980.

8. Šarić G, Matković D, Hruškar M, Vahčić N. Characterisation and classification of Croatian honey by physicochemical parameters. Food Technology and Biotechnology. 2008;46:355-367.

9. Ruoff K. Authentication of the Botanical Origin of Honey. Doctoral Dissertation. Zürich; 2006.

10. Uršulin-Trstenjak N, Levanić D, Šušnić V, Šušnić S. Profile and diversity of physicochemical parameters of the black locust honey from eastern Croatia region given the testing seasons. Journal of Hygienic Engineering and Design. 2015; 9 (1):26-34. 
11. EU - Council Directive 2001/110/EC of 20 December 2001 relating to honey, Official Journal of the European Communities L. 2010; 10: 47-52.

12. Ministarstvo poljoprivrede, ribarstva i ruralnog razvoja RH. Pravilnik o medu. Narodne novine 93/09. 2009a.

13. Persano Oddo L \& Bogdanov S. Determination of honey botanical origin. Apidologie. 2004; 35:S2-S3.

14. Bogdanov S, Ruoff K \& Persano Oddo L. Physico-chemical methods for the characterisation of unifloral honeys: a review. Apidologie. 2004; (special issue) 35:4-17.

15. Deutsches Institut für Normung. Determination of relative pollen content of honey. DIN 10760:2002-05.

16. International Honey Commission. [online] Harmonised methods of the International (European) Honey Commission. 2009. Available: http://www.bee-hexagon.net/files/ file/fileE/IHC-methods_2009.pdf (Accessed 02.25.2009).

17. Schweizerisches Lebensmittel. Buch: SLMB, Kapitel 23A Honig. Bestimmung der Amylactivität (nach Phadebas). Bern: EDMZ; 1995.

18. StatSoft Inc. Statistica 9.1. Single user version, Zagreb: University of Zagreb; 2010.

19. Ministarstvo poljoprivrede, ribarstva i ruralnog razvoja $\mathrm{RH}$ : Pravilnik o kakvoći uniflornog meda, Narodne novine 122/09. 2009b.

20. Mateo R \& Bosch-Reig F. Classification of Spanish unifloral honeys by discriminant analysis of electrical conductivity, color, water content, sugars and $\mathrm{pH}$. Journal of Agricultural and Food Chemistry. 1998; 46:393-400.
21. Persano Oddo L, Piana L, Bogdanov S, Bentabol A, Gotsiou $P$, Kerkivliet J et al. Botanical species giving unifloral honey in Europe. Apidologie. 2004; 35:S82-S93.

22. Bogdanov S, Lüllmnn C \& Martin P. Honey quality, methods of analysis and international regulatory standards: Review of the work of the International Commission. Mitteilungen aus Lebensmitteluntersuchung und $\mathrm{Hy}$ giene. 1999; 90:108-25.

23. Marghitas LA, Dezmirean DS, Pocol CB, Ilea M, Bobis O, Gergen I. The development of a biochemical profile of black locust honey by identifying biochemical determinants of its quality. Notulae Botanicae Hort I Agrobotanici Cluj-Napoca. 2010; Special Issue; 38:84-90.

24. Kenjerić D, Mandić M L, Primorac Lj, Bubola D \& Perl A. Flavonoid profile of Robinia honeys produced in Croatia. Food Chemistry 2007; 102:683-90.

25. Persano Oddo L \& Piro R. Main European unifloral honeys: descriptive sheets. Apidologie. 2004; 35:S38-S81.

26. Golob T \& Plestenjak A. Quality of Slovene honey. Food Technology and Biotechnology. 1999; 37:195-201.

27. Popek S. A procedure to identify honey type. Food Chemistry. 2002; 79:401-6.

28. Primorac Lj, Flanjak I, Kenjerić D, Bubola D \& Topolnjak Z. Specific rotation and carbohydrate profile of Croatian unifloral honeys. Czech Journal of Food Sciences. 2011; 29:515-9. 


\section{FIZIKALNO-KEMIJSKI PROFILI HRVATSKOG MEDA S PRIKAZOM POTROŠNJE MEĐU STUDENTIMA ZDRAVSTVENOG USMJERENJA}

1 Natalija Uršulin-Trstenjak

1 Davor Levanić

1 Ivana Grabar

1 Marijana Koldenjak

2 Jasna Bošnir

1 Sveučilište Sjever, Sveučilišni centar Varaždin, Varaždin

2 Nastavni zavod za javno zdravstvo „Dr. Andrija Štampar”, Zagreb

\section{Sažetak}

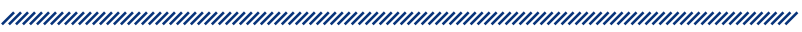

Potrošači postaju sve svjesniji potrošnje meda - hrane sa svojstvima korisnima za zdravlje.

U skladu s Direktivom Vijeća Europske unije o medu, kao i sa sadašnjim zakonodavstvom u Republici Hrvatskoj, zahtjev za označavanje botaničkog podrijetla meda nektara jest prisutnost dominantnoga cvjetnog peluda te senzorska i fizikalno-kemijska analiza.

Rad je prikaz potvrde botaničkog podrijetla i profila fizikalno-kemijskih parametara meda s razlikama u sezoni/regijama, kao i potrošnje meda.

Ovim istraživanjem obuhvaćeno je 200 uzoraka meda bagrema, prikupljenih od pčelara kroz dvije sezone u pet hrvatskih regija - 20 uzoraka iz svake regije. Istraživanje je provedeno na 151 studentu kako bi se prikupile informacije o navikama konzumacije meda među studentima.
U radu su primijenjene sljedeće metode istraživanja: melisopalinološka i fizikalno-kemijska analiza, test ANOVA i anketa.

Svi ispitani uzorci sadrže dovoljan broj peludnih zrnaca $>20 \%$ Robiniapseudoacacia. Rezultatisu fizikalno-kemijskih parametara kvalitete sljedeći: voda 15,99 - 18,03\%, slobodne kiseline 8,16 - 12,94 mEq / 1000 g, električna vodljivost $0,12-0,22 \mathrm{mS} / \mathrm{cm}$, reducirajući šećeri 66,94 - 70,88 g / $100 \mathrm{~g}$, saharoza 0,10 - 2,90 g / $100 \mathrm{~g}$, dijastaza 9,07 - 15,14 DN, HMF 0,50 - 18,99 mg/kg.

Provedena analiza varijance podataka unutar fizikalnokemijskih parametara s obzirom na sezone i regije pokazuje da postoji statistički značajna razlika ( $p$-vrijednost) među sezonama $(p<0,05)$ za vodu, dok aktivnost dijastaze pokazuje statistički značajnu razliku između regija $(p<0,05)$.

Od $93 \%$ (141) ispitanika koji konzumiraju med, $44 \%$ (63) ih konzumira med u količinama manjima od hrvatskog prosjeka.

Ključne riječi: bagremov med, fizikalno-kemijski parametri, botaničko podrijetlo 